\title{
Crustal structure and upper mantle anisotropy of the Afar triple junction
}

\author{
U. Kumar ${ }^{1}$, C. P. Legendre ${ }^{1,2^{*}}$ (I) and B. S. Huang ${ }^{1}$
}

\begin{abstract}
The Afar region is a tectonically distinct area useful for studying continental break-up and rifting. Various conflicting models have been suggested to explain the lateral variations of the anisotropy in this region. To address this issue, we investigated the tectonics of the Afar region using receiver function and shear-wave splitting measurements based on broadband seismic data from 227 stations in the region. Further, the receiver function results were inverted to obtain the crustal thickness and $V_{p} / V_{s}$ ratio of the region. Our results reveal a thick African crust (thicker than 40 $\mathrm{km}$ ) with typical $V_{\mathrm{p}} / V_{\mathrm{s}}$ values for the continental crust, elongated down to $21 \mathrm{~km}$ along the rift system with very high $V_{p} / V_{s}$ values near the fractured zones, suggesting crustal thinning near the fractured zones. Our shear-wave splitting measurements indicate a general fast axis orientation of N030E. However, substantial disparities in the fast anisotropy direction exist in the triple junction region, with some stations displaying a direction of N120E, which is perpendicular to the fast directions measured at the surrounding stations. In addition, many stations located close to the rifts and within the Arabian Plate provide mostly null measurements, indicating the presence of fluids or isotropic media. This study uses several methodologies to unravel the structure and evolution of the Afar region, providing valuable insight into the Afar, a tectonically distinct region, which will be useful for elucidating the mechanisms and characteristics of a continental break-up and the rifting process.
\end{abstract}

Keywords: Afar, Continental break-up, Continental rifting, Crustal structure, Receiver function, Shear-wave splitting

\section{Introduction \\ Geological settings}

The Afar triple junction (Fig. 1) is located in East Africa connecting three branches of a complex rift system. This area is an example of the last stage of continental rifting and the early stage of seafloor spreading, leading to the creation of oceanic crust (Mohr 1970; Tesfaye et al. 2003; Rychert et al. 2012). The Afar hotspot is located at the triple junction between the Red Sea rift, the Gulf of Aden, and the Ethiopian rift zone (Mohr 1970; Legendre 2013). The Red Sea rift is considered as the boundary between the Arabian and African (Nubian) plates, whereas the Gulf of Aden separates the Arabian and African (Somalian) plates (Bird 2003). The Ethiopian rift zone (also

\footnotetext{
*Correspondence: legendre@Earth.sinica.edu.tw

${ }^{1}$ Institute of Earth Sciences, Academia Sinica, Taipei, Taiwan

Full list of author information is available at the end of the article
}

called East African Rift System), an active continental rift zone in East Africa, is a divergent tectonic plate boundary (Kusky et al. 2010) dividing the African Plate into two tectonic units: the Nubian and Somalian plates (Garfunkel and Beyth 2006). The Afar triple junction accommodates the divergent motions between the Arabian, Nubian, and Somalian plates along the Red Sea, Gulf of Aden, and East African rifts. The kinematics of the Afar triple junctions are generally studied using long-term deformation and geodetic observations (McClusky et al. 2010) as well as geodynamical modeling (Koptev et al. 2018).

The opening of the Red Sea and the Gulf of Aden started in the Late Eocene-Early Oligocene (Ghebreab 1998) and lead to the split between Africa and Arabia in the Early Miocene (Joffe and Garfunkel 1987). The early stage of the collision between the Mediterranean and Biltis segments (McQuarrie et al. 2003) occurred 


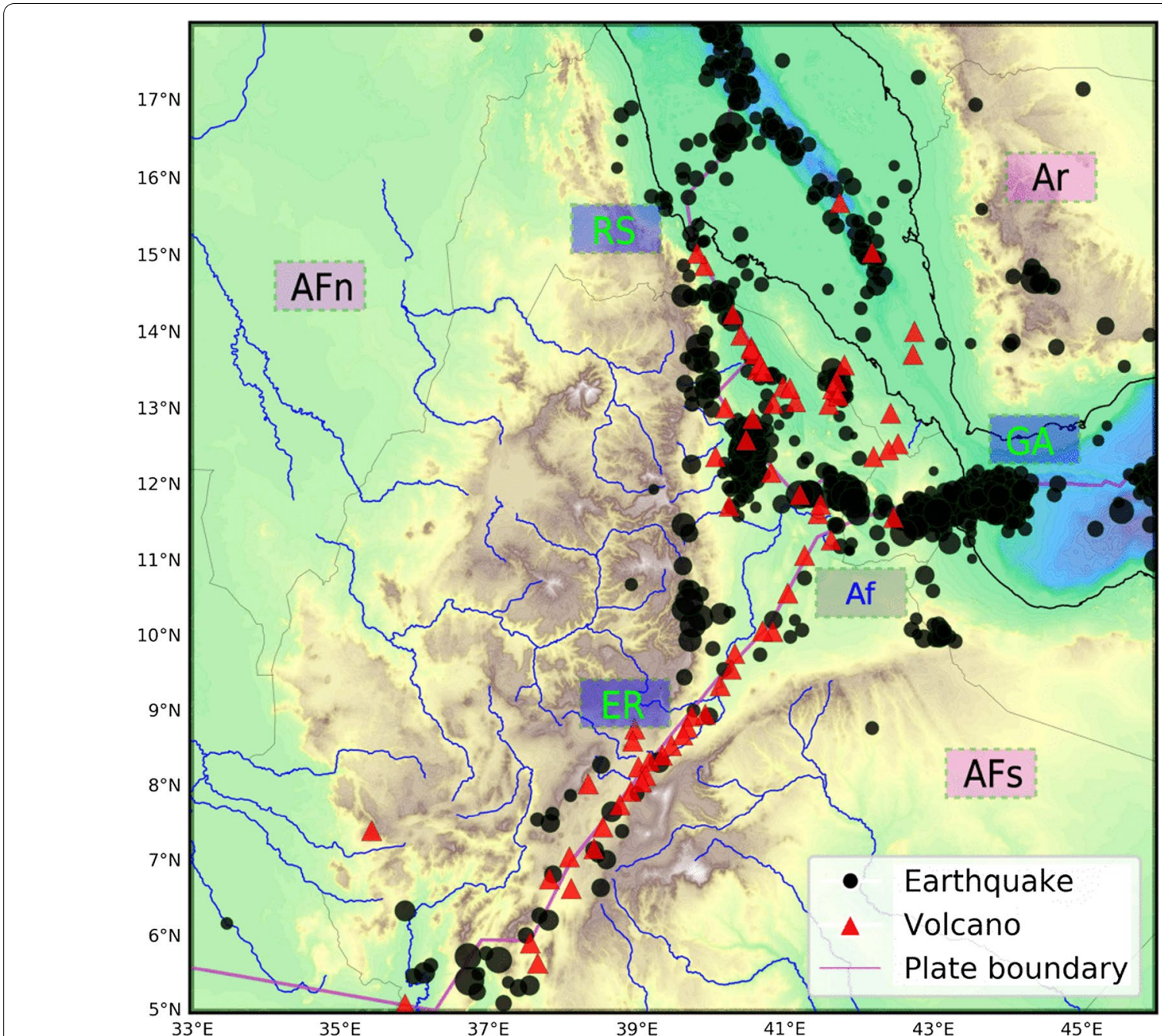

Fig. 1 Tectonic setting of the Afar triple junction. The red triangles are active Holocene volcanoes (Venzke 2013). The magenta line represents the plate boundary (Bird 2003). The black circles represent the locations of the epicenters of Earthquakes $\left(M_{w}>4\right)$. Most of the Earthquakes in the region have shallow depths. The black text framed in magenta provides the names of the different plates (Bird 2003): AFn, African (Nubian) plate; AFs, African (Somalian) plate; Ar, Arabian plate. The green text framed in blue provides the names of the three rifts: ER, Eden rift; GA, Gulf of Aden; R,- Red Sea rift. The blue text framed in brown (Af) indicates the location of the Afar triple junction

synchronously with the massive eruption of flood basalt associated with the Afar plume at around $30 \mathrm{Ma}$ (Hofmann et al. 1997).

\section{Previous geophysical studies}

Several geophysical tools have been employed in this region to investigate its tectonics. In recent decades, the Global Positioning System (GPS) has been widely deployed in this region to investigate the relative motions of the different tectonic units (Walpersdorf et al. 1999; McClusky et al. 2010; Doubre et al. 2017).

The main results of geodetic measurements along the Afar triple junction have suggested counterclockwise rotation with respect to the Nubian Plate (with a rotation pole located in the central Red Sea). Doubre et al. (2017), based on a combination of GPS and Interferometric Synthetic Aperture Radar (InSAR) measurements, suggested that the northern part of the Somalia plate evolves independently from the entire African (Somalian) plate.

Previous seismological models from body-wave tomography (Benoit et al. 2006; Koulakov 2007) and surfacewave tomography (Sebai et al. 2006; Guidarelli et al. 2011; Legendre 2013) corroborated the presence of negative velocity anomalies beneath the triple rift systems. Also, they have suggested that the Afar hotspot and other volcanic provinces in the region (Wignall 2001; Mège and 
Korme 2004) are originating from the African superplume (Ni et al. 2002; Simmons et al. 2007), upwelling from the lower mantle.

The crustal thickness in the region is of great interest as it is crucial to unraveling the mechanisms of the tectonic evolution of the Afar triple junction. The Moho depth has been widely investigated using the receiver function technique (Dugda et al. 2005; Dugda and Nyblade 2006; Hammond et al. 2011; Reed et al. 2014; Thompson et al. 2015) and the crustal thickness ranges from $\sim 15 \mathrm{~km}$ beneath the spreading centers up to $\sim 40-45 \mathrm{~km}$ outside the continental break-up area (Hammond et al. 2011).

Previous anisotropy observations have mainly been achieved by the shear-wave splitting of teleseismic (Gashawbeza et al. 2004; Walker et al. 2005) or local Earthquakes (Keir et al. 2011). Several other shear-wave splitting measurements performed in the region and surroundings have been compiled into international shearwave splitting databases (Wüstefeld et al. 2009; IRIS 2012). Deformation-related structures generally explain the anisotropic pattern in the Afar region. The general orientation of the anisotropies is associated with mantle flow; in contrast, subtle changes in the fast direction are related to the presence of fluids, isotropic media, or vertical mantle flow. Dyke-induced faulting and alignment of melt pockets near volcanic centers also have very distinct anisotropic patterns in the region (Gashawbeza et al. 2004).

\section{Tectonics of the Afar triple junction}

The tectonics of the Afar triple junction is dominated by the motion of three plates: Arabia, Africa (Nubia), and Africa (Somalia). The first rift to open is thought to have been the Gulf of Aden around $30 \mathrm{Ma}$ (Ghebreab 1998). Simultaneously, the intense activity of the Afar hotspot (Schilling et al. 1992; Hofmann et al. 1997) led to a massive amount of flood basalt in the region. The opening of the Red Sea rift (Kusky et al. 2010) is thought to have started between 24 and $21 \mathrm{Ma}$. This event was followed by high magnetic anomalies (Wignall 2001; Mège and Korme 2004) and subsequently the opening of the Ethiopian rift between 18 and $15 \mathrm{Ma}$ (Kusky et al. 2010). The local seismicity (Abdallah et al. 1979; Illsley-Kemp et al. 2018), surface displacement (Walpersdorf et al. 1999; Kusky et al. 2010) and geometry of the active faults (Doubre et al. 2017) were used to fine-tune the geometry and complexity of the tectonic units interacting in the region. Further information from body-wave tomography (Benoit et al. 2006) and surface-wave tomography (Guidarelli et al. 2011), as well as receiver function results (Hammond et al. 2011), have provided additional constraints on the nature of these tectonic units, such as their lateral and vertical extensions and the presence of rigid blocks in the region. Further geophysical modeling (Simmons et al. 2007; Reilinger and McClusky 2011) has enabled the kinematics and dynamics of the region to be refined. However, conflicting models have been suggested to explain the lateral variations of the anisotropy in the Afar triple junction region. Gao et al. (2010) suggested that the optimal source of anisotropy is located at approximately $300 \mathrm{~km}$ depth (in the asthenosphere), whereas Keir et al. (2011) found that this anisotropy originates mostly from deformation-related structures in the crust and lithosphere.

In this study, we performed a systematic investigation of the crustal structure and mantle anisotropy in the Afar region by means of receiver function and shear-wave splitting analyzes. Knowledge about the crustal thickness as well as crustal and lithospheric anisotropies (Legendre et al. 2017, 2020) can provide helpful insight into the crustal and mantle flow affecting the regional dynamics (Legendre et al. 2016; Fan et al. 2020). The main contribution of this study is a total of 431 new shear-wave splitting measurements in the region as well as 34 measurements of crustal thickness and ratio of seismic compressional and shear-wave velocities $\left(V_{\mathrm{p}} / V_{\mathrm{s}}\right)$. In the first step, we will describe the data and methodologies used in this study ("Data and methods"). "Results" presents our new findings based on crustal thickness, velocity ratio between compressional waves and shear waves as well as shear-wave splitting of the SKS phase. "Discussion" discusses the implications of our computed crustal depth, $\frac{V_{\mathrm{p}}}{V_{\mathrm{s}}}$ ratio, and anisotropy in terms of the structures, composition, and evolution of local and regional features.

\section{Data and methods}

\section{Seismological data}

We searched for all available broadband seismic stations deployed in the study region (Fig. 2). In total, 227 stations were found, but only 223 used for receiver functions and 224 used for shear-wave splitting constraints provided sufficient data for further investigation. To compute the receiver functions, we selected each available Earthquake with $M_{\mathrm{w}}>5.5$ and an epicentral distance between $30^{\circ}$ and $90^{\circ}$, and to perform the shear-wave splitting measurements at each station, we selected Earthquakes with $M_{\mathrm{w}}$ $>6.5$ with epicentral distances ranging from $90^{\circ}$ to $120^{\circ}$.

We selected the accessible Earthquakes independently for each station. The number of Earthquakes mainly varies with the station operating time. We selected 427 events among all stations to compute the receiver functions and 514 for the shear-wave splitting measurements. Waveform data were downloaded from global openaccess data centers (mostly from the GEOFOrschungsNetz program (GEOFON), GeoForschungsZentrum Potsdam, Observatories and Research Facilities for 


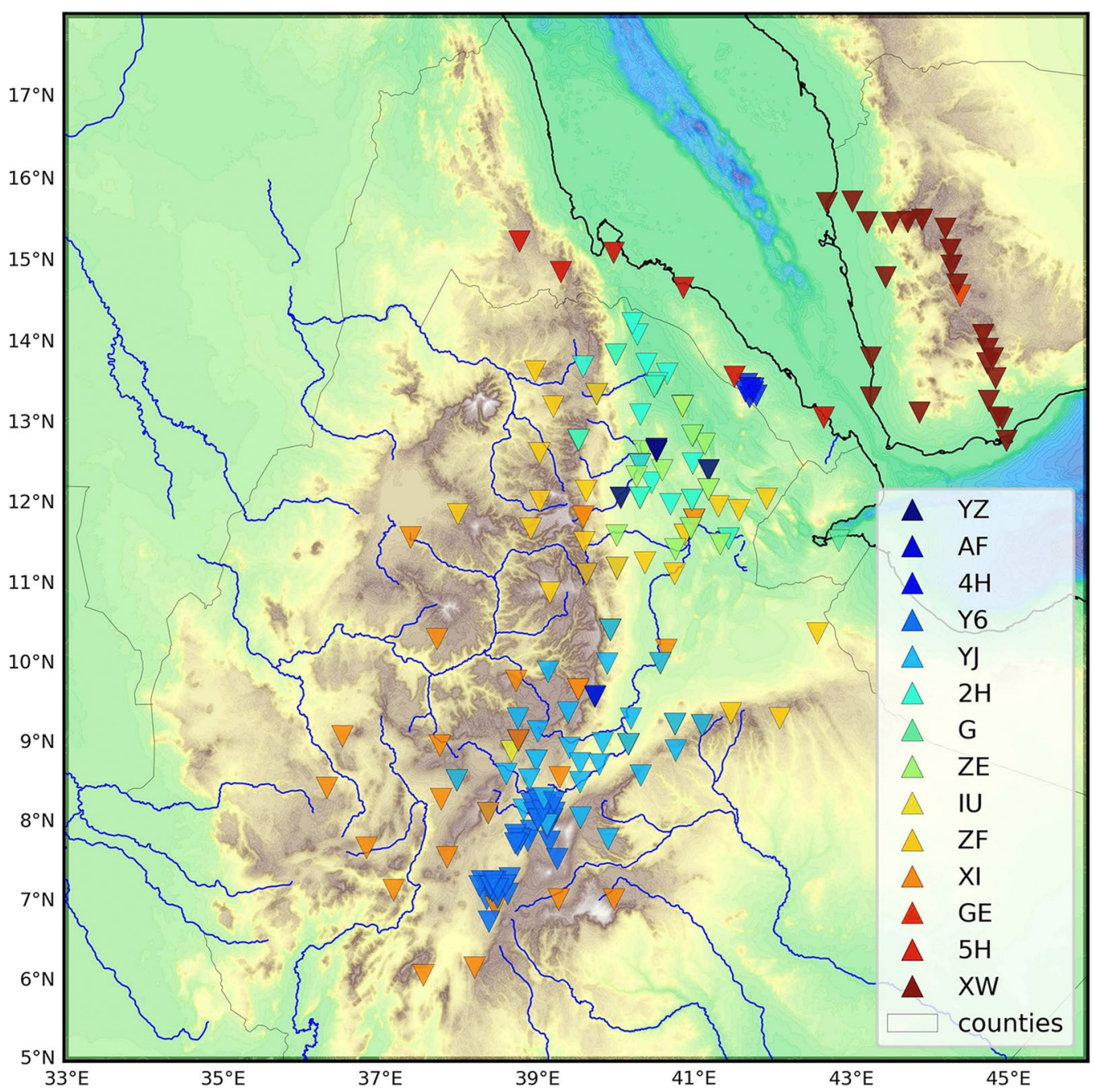

Fig. 2 Locations of the 227 seismic stations deployed in Afar region. The color code indicates the networks to which the stations belong

European Seismology Data Center and Incorporated Research Institutions for Seismology Data Management Center) (Megies et al. 2011; Trabant et al. 2012).

\section{Receiver functions}

Receiver functions are time series representing the internal boundaries of the Earth near the receiver, converting the incident $\mathrm{P}$ waves into $\mathrm{S}$ waves, or vice versa. The receiver function method is well established and widely used to investigate crustal and upper mantle velocity discontinuities (Langston 1979; Ammon et al. 1990; Zhu and Kanamori 2000; Kind et al. 2015; Maguire et al. 2018).

Herein, we illustrate the method implemented by Eulenfeld (2020) using a single station, ZF-MAYE. Figure 3 summarizes the potential events selected for this station and satisfying the magnitude and epicentral distance requirements.
The ZRT coordinates (vertical, radial, and transverse components) were conveniently adopted for the nearly vertical incidence of teleseismic events. Assuming the location of the station-hypocenter pair is known, it is possible to infer the wave coordinate system. The $\mathrm{L}$ component is associated with the P-wave polarization, whereas the $\mathrm{Q}$ component is tied to $\mathrm{S}_{\mathrm{V}}$-wave polarization, and the $\mathrm{T}$ component is related to the $\mathrm{S}_{\mathrm{H}}$-wave polarization.

In this study, the particle motions of the incident and converted waves were separated using the wave coordinates. To derive the P-receiver functions, the teleseismic waveform of the $\mathrm{L}$ (or $\mathrm{Z}$ ) component (assumed to resemble that of a $\mathrm{P}$ wave striking the conversion boundary) is deconvolved from the QT (or RT) components to separate the source effects of the converted phases. The resulting receiver function (the $\mathrm{Q}$ component in particular) reveals the delay time (relative to the P-wave onset) 


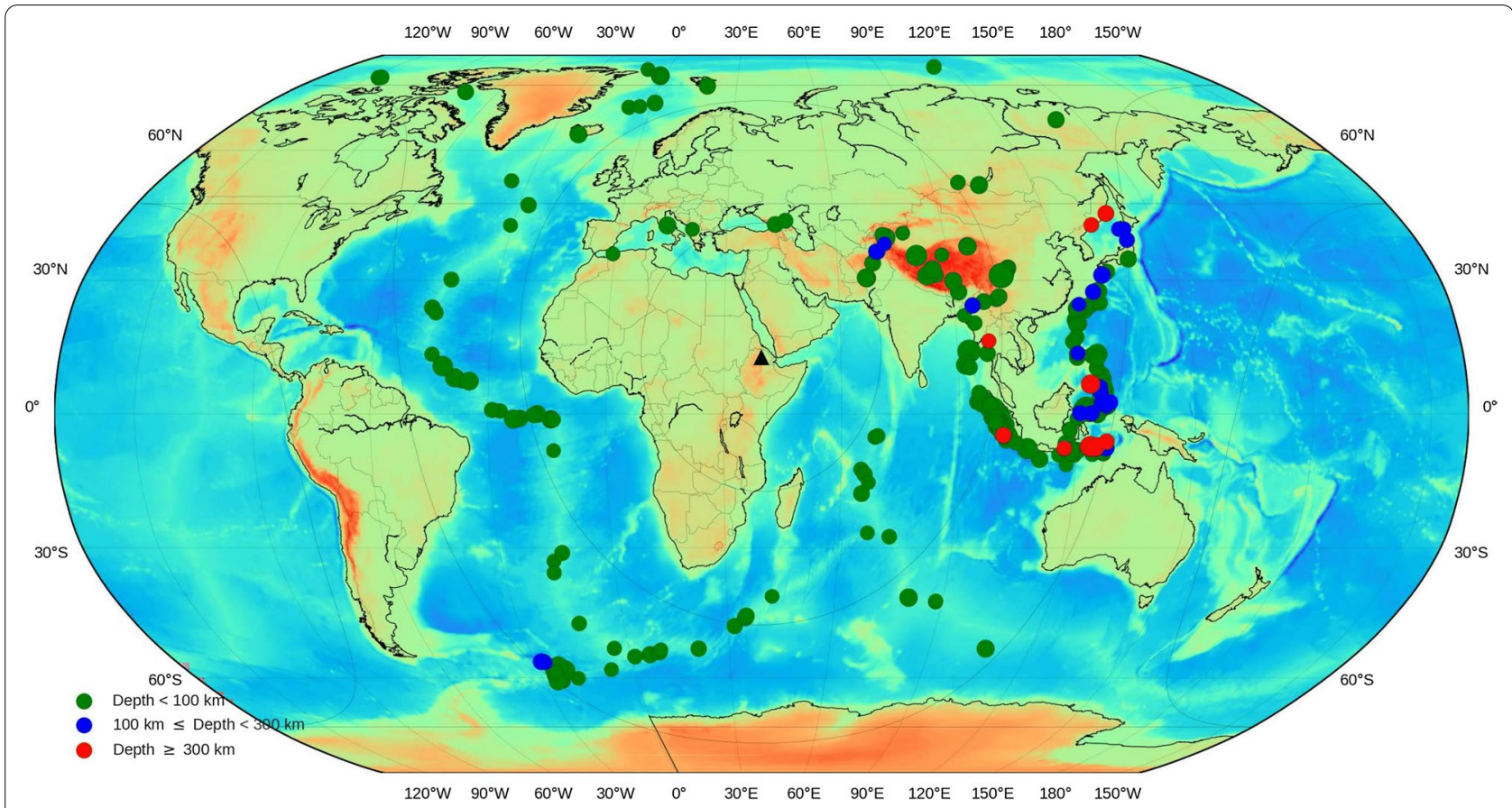

Fig. 3 Selected events used to compute the receiver functions for a single seismic station (ZF-MAYE). The seismic station is indicated by a black triangle, and the locations of the events are marked by circles, color-coded by epicentral depth

and relative amplitudes of the $\mathrm{P}$ waves converted into $\mathrm{S}$ waves (Ps) by the significant discontinuity, as well as multiples $\left(\mathrm{P}_{\mathrm{P}} \mathrm{P}_{\mathrm{mP}} \mathrm{P}_{\mathrm{p}} \mathrm{S}_{\mathrm{mP}}, \mathrm{P}_{\mathrm{P}} \mathrm{P}_{\mathrm{mS}}\right.$, and $\left.\mathrm{P}_{\mathrm{p}} \mathrm{S}_{\mathrm{mS}}\right)$ caused by reverberations within the layer. $\mathrm{P}$ indicates a $\mathrm{P}$-wave in the mantle, $\mathrm{p}$ indicates a P-wave ascending to the surface, $\mathrm{S}$ indicates an $\mathrm{S}$-wave in the mantle, $\mathrm{s}$ indicates an $\mathrm{S}$-wave ascending to the surface, whereas $\mathrm{m}$ indicates a top-side reflection from the Moho.

Those phases are not easily identified on a seismogram, because they generally have low amplitude and are hidden in the coda of teleseismic P-wave coda. A conventional approach is to build the receiver function, and to highlight those compressional motion converted into shear-polarized motion. The underlying assumption is that the vertical component is primarily related to the compressional motion. Thus, deconvolving it from the horizontal components removes the signature of the Earthquake source (present in both horizontal and vertical components of the seismogram), as well as all compressional reverberations. The resulting product of the deconvolution is the time series of shear motion within the teleseismic P-wave coda. More details about the deconvolution process are available at Walpole et al. (2014) and Kumar and Legendre (2021).

The horizontal components of the seismogram are rotated into LQT components ( $\mathrm{L}$ is aligned in the direction of $\mathrm{P}$ wave propagation; $\mathrm{Q}$ is aligned in the direction of the $S_{v}$ phase movement whereas $T$ is aligned in the direction of the $S_{H}$ phase movement).

The $\mathrm{L}$ and $\mathrm{Q}$ receiver functions are obtained by deconvolving the vertical component seismogram of a single teleseismic event from the $\mathrm{L}$ and $\mathrm{Q}$ components seismogram, respectively, using the time domain source equalization method of Langston (1979), as shown in Eq. (1):

$$
\begin{aligned}
\operatorname{RF}_{\mathrm{L}}(\omega) & =c(\omega) \cdot \frac{\mathrm{L}(\omega)}{\mathrm{Z}(\omega)}, \\
\mathrm{RF}_{\mathrm{Q}}(\omega) & =c(\omega) \cdot \frac{\mathrm{Q}(\omega)}{\mathrm{Z}(\omega)} .
\end{aligned}
$$

Figure 4 displays the receiver functions computed at the selected station (ZF-MAYE).

\section{$H-\kappa$ stacking}

We stacked all receiver functions that were reasonable for each station to produce an average receiver function for that station (Fig. 4, top). Stacking receiver functions enhances the signal-to-noise ratio of the trace, thereby increasing the amplitude of the converted phases in the receiver function. Theoretically, all converted phases should be visible on the stacked receiver function. However, some converted phases have very low amplitudes and are not easy to discriminate. 


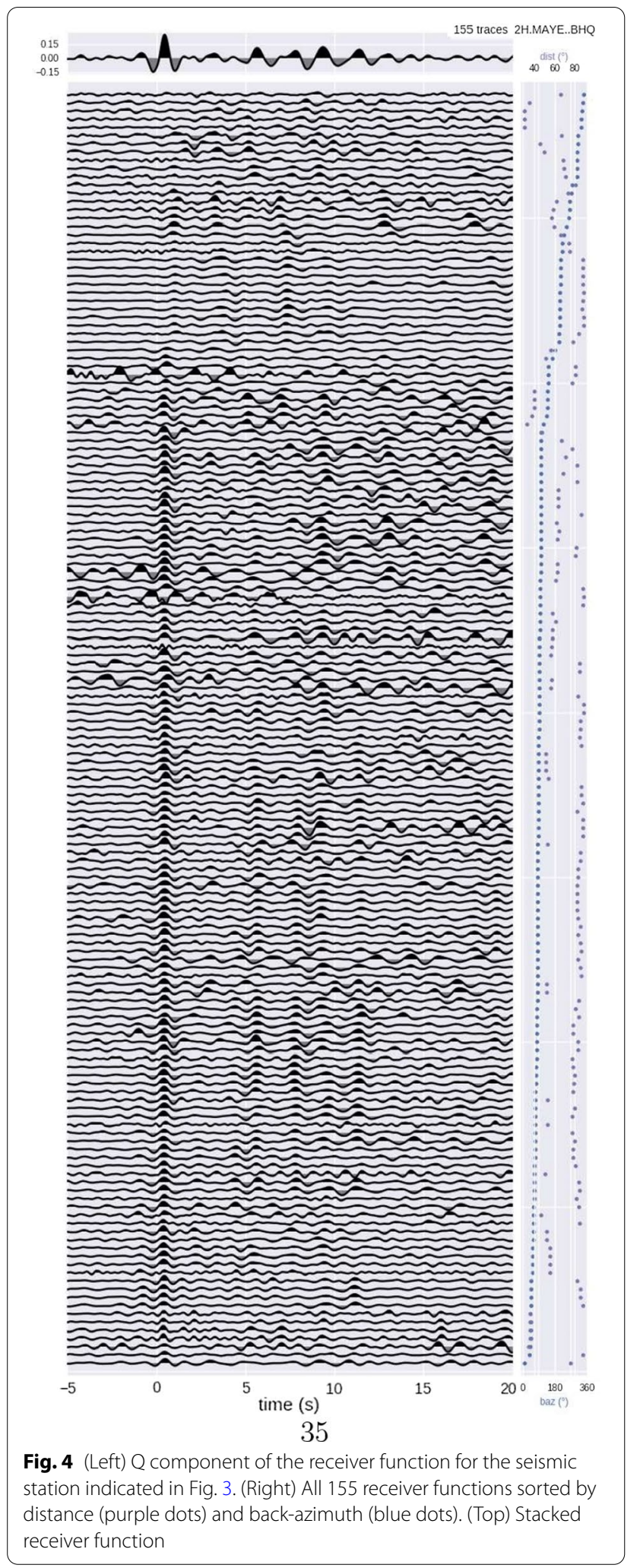

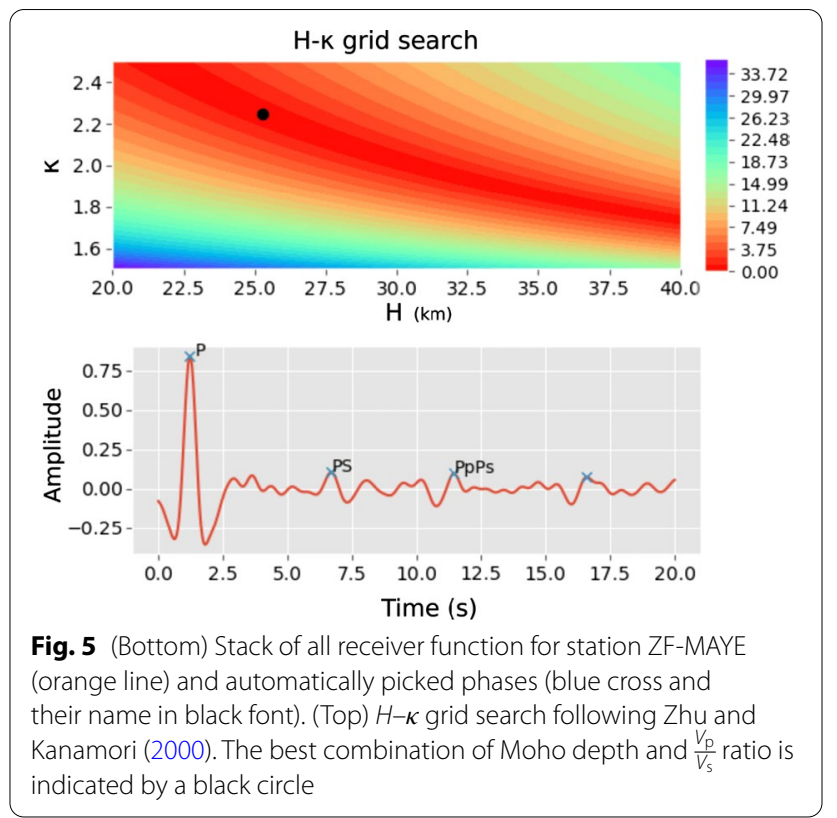

To ensure the reliability of the $H-\kappa$ stack, we selected only the receiver functions that were of high quality and discarded those with more uncertainty. In a first step, we discarded all receiver functions that had a signal-to-noise ratio lower than 3 . Only the receiver functions with clear direct $\mathrm{P}, \mathrm{PS}$, and $\mathrm{P}_{\mathrm{P}} \mathrm{P}_{\mathrm{S}}$ phases were retained. We used an automated tool (Eulenfeld 2020; Kumar and Legendre 2021) to identify the potential phases in the stacked seismogram (Fig. 5, bottom) where only the phases with strong amplitude contrasts were easily recognized. We set the first peak with the highest amplitude as the direct P-wave arrival. The first peak with an amplitude more significant than $10 \%$ of the P-wave arrival amplitude was considered to correspond to the P-to-S converted (PS) wave. The second peak with an amplitude greater than $5 \%$ of the P-wave arrival amplitude was considered the $\mathrm{P}_{\mathrm{P}} \mathrm{P}_{\mathrm{S}}$ wave.

The conventional $H-\kappa$ stacking method (Zhu and Kanamori 2000) requires another phase: the $\mathrm{P}_{\mathrm{p}} \mathrm{S}_{\mathrm{s}}$ or $\mathrm{P}_{\mathrm{s}} \mathrm{P}_{\mathrm{S}}$ that arrive $15-20 \mathrm{~s}$ after the direct $\mathrm{P}$ arrival. However, this phase has a negative amplitude and was not always picked by our automated picking method. Therefore, we only use those three arrival times to constrain the Moho depth $(H)$ as well as the $\frac{V_{\mathrm{p}}}{V_{\mathrm{s}}}$ ratio $(\kappa)$, following:

$$
\begin{aligned}
& H=\frac{\left(t_{1}-t_{0}\right)}{\sqrt{\left(\frac{\kappa}{V_{\mathrm{p}}}\right)^{2}-p^{2}}-\sqrt{\left(\frac{1}{V_{\mathrm{p}}}\right)^{2}-p^{2}}}, \\
& H=\frac{\left(t_{2}-t_{0}\right)}{\sqrt{\left(\frac{\kappa}{V_{\mathrm{p}}}\right)^{2}-p^{2}}-\sqrt{\left(\frac{1}{V_{\mathrm{p}}}\right)^{2}-p^{2}}},
\end{aligned}
$$


where $t_{0}$ is the arrival time of the $\mathrm{P}$ wave, $t_{1}$ is the arrival time of the PS wave, $t_{2}$ is the arrival time of the $\mathrm{P}_{\mathrm{p}} \mathrm{P}_{\mathrm{s}}$ wave, $V_{\mathrm{p}}$ is set to $6.3 \mathrm{~km} / \mathrm{s}$ (based on the IASP91 reference model from Kennett et al. (1995), $\kappa$ is the $\frac{V_{\mathrm{p}}}{V_{\mathrm{s}}}$ ratio. $H$ is the Moho depth (in $\mathrm{km}$ ). A 65\% weight was given to the $P S$ arrival time in Eq. (2) and $35 \%$ was given to the $\mathrm{P}_{\mathrm{p}} \mathrm{P}_{\mathrm{s}}$ arrival time, following Zhu and Kanamori (2000). Note that the calculated crustal thickness is strongly influenced by the initial velocity model, which is also affected by the thickness of the sedimentary layer.

For each station where the stacked receiver function displayed enough amplitude on the selected phases, both Moho depth $(H)$ and $\frac{V_{\mathrm{p}}}{V_{\mathrm{s}}}$ ratio $(\kappa)$ could be retrieved, as displayed in Fig. 10.

Some receiver functions failed to provide enough energy at the predicted arrival times for the $\mathrm{P}_{\mathrm{P}} \mathrm{P}_{\mathrm{S}}$ phase due to the instability of the deconvolution (Kind et al. 2015). Of the 223 seismic stations that provided data for receiver function inversion, 34 also supplied measurements for the $H-\kappa$ stacking method (Zhu and Kanamori 2000). Most stations provided receiver functions results, but we imposed highly restrictive quality checks to ensure that the $H-\kappa$ stacking method would yield consistent results. The quality checks consist of two steps: first, the receiver function requires a signal-to-noise ratio higher than 3 . Then all the phases used for the $H-\kappa$ stacking method need to be consistently determined for each station specific stacked receiver function.

\section{Shear-wave splitting}

Shear-wave polarization anisotropy from core phases is a well-established concept (Ando et al. 1983; Fukao 1984; Obrebski et al. 2010). To download and process the data, we followed the workflow of STADIUM-py (Walpole et al. 2014).

For each seismic event that matches the magnitude and epicentral distance requirements (Fig. 6), ZNE raw data were downloaded and rotated from ZNE to ZRT components. The predicted arrival time of the SKS phase was calculated using the IASP91 reference model (Kennett et al. 1995). The traces were cut around the SKS phase predicted arrival time (from $30 \mathrm{~s}$ before to $45 \mathrm{~s}$ after the predicted time), as displayed in Fig. 7.

We then used an automatic selection approach to identify the beginning and ending times of the SKS wave on the radial component (Fig. 8). Characteristic functions calculated using short-term-average/ long-term-average (STA/LTA) algorithms are often employed for automated detection of $\mathrm{P}$ and $\mathrm{S}$ waves and arrival time estimation (Walpole et al. 2014). This study used an automatic selection method based on an STA/LTA algorithm to determine the SKS arrival time accurately. Two threshold values in the characteristic function were set to pick the beginning and end times of the SKS wave accurately (Walpole et al. 2014): the first threshold was for the beginning of the SKS phase,

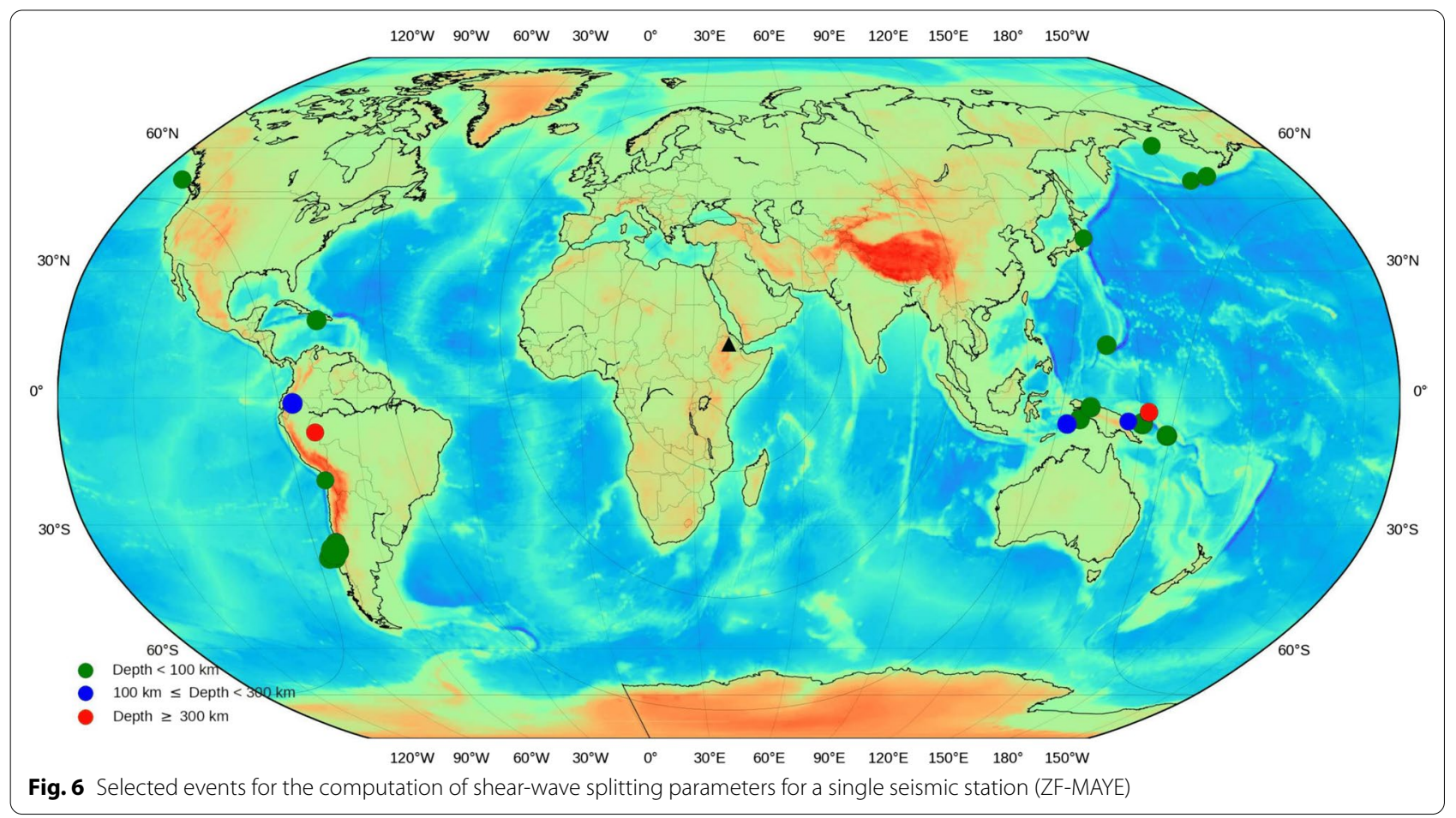



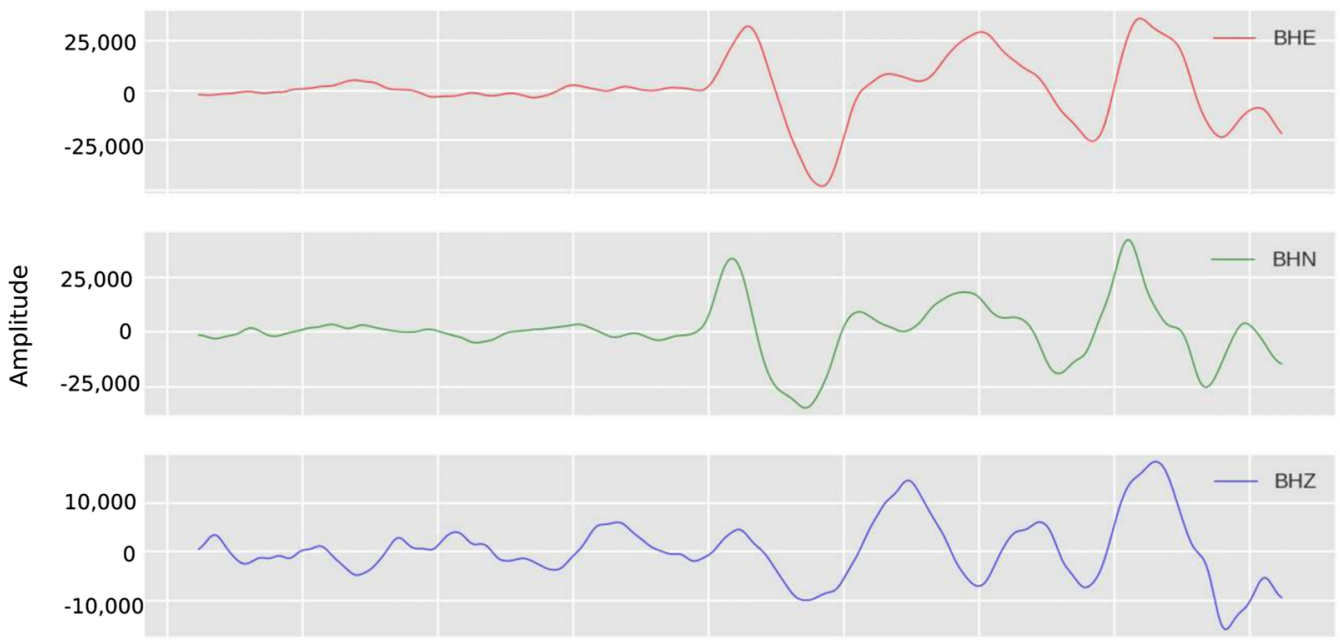

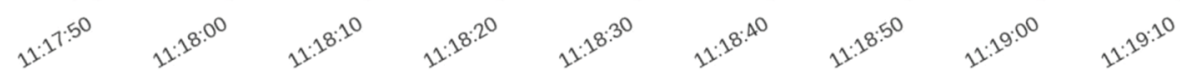

Time

Fig. 7 Raw waveforms of unfiltered ZNE components for an event recorded at station ZF-MAYE (8/9/2009, 10:55:56.28, epicenter (33.1474, 138.0594), epicentral depth of $302.2 \mathrm{~km}$, and $M_{\mathrm{w}}=7.1$
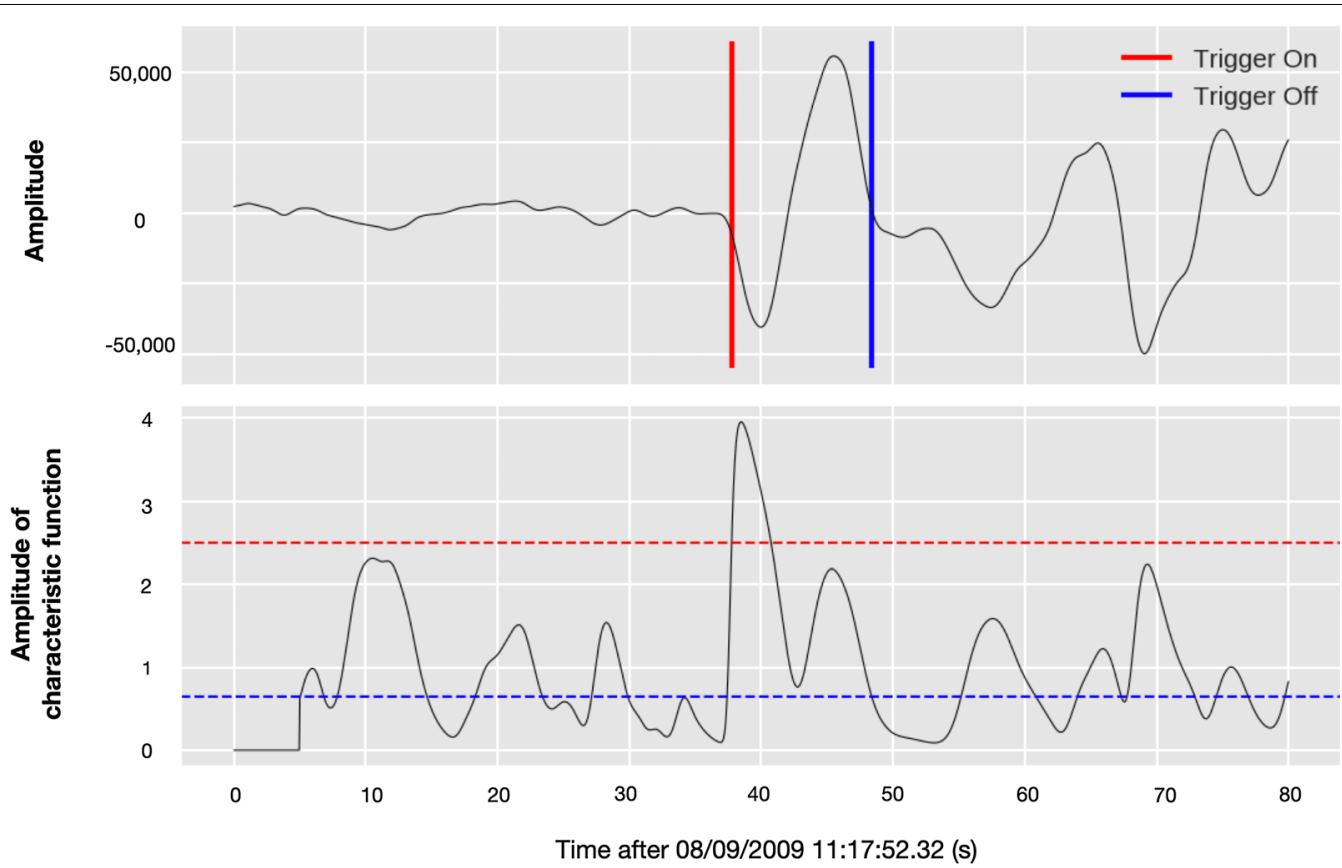

Fig. 8 Automatic selection of the SKS phase using the recursive STA LTA method for the trace depicted in Fig. 7. The red and blue bars indicate the beginning and ending times of the SKS phase, based on values of the characteristic function (bottom)

and the second was for the end of the SKS phase (red and blue lines in Fig. 8, respectively).

Once the SKS phase had been selected, we performed a grid search (Fig. 9) for the best-fitting splitting parameters following (Walpole et al. 2014). To pass the grid search successfully, we set some thresholds on the errors in the phase $(\delta \phi)$ and the delay time $(\delta t)$. Measurements with excessive uncertainties in the fast directions $\left(\delta \phi>7^{\circ}\right)$ and the delay time $(\delta t>1.5 \mathrm{~s})$ were also been discarded. Those threshold values in the phase $(\delta \phi)$ and 

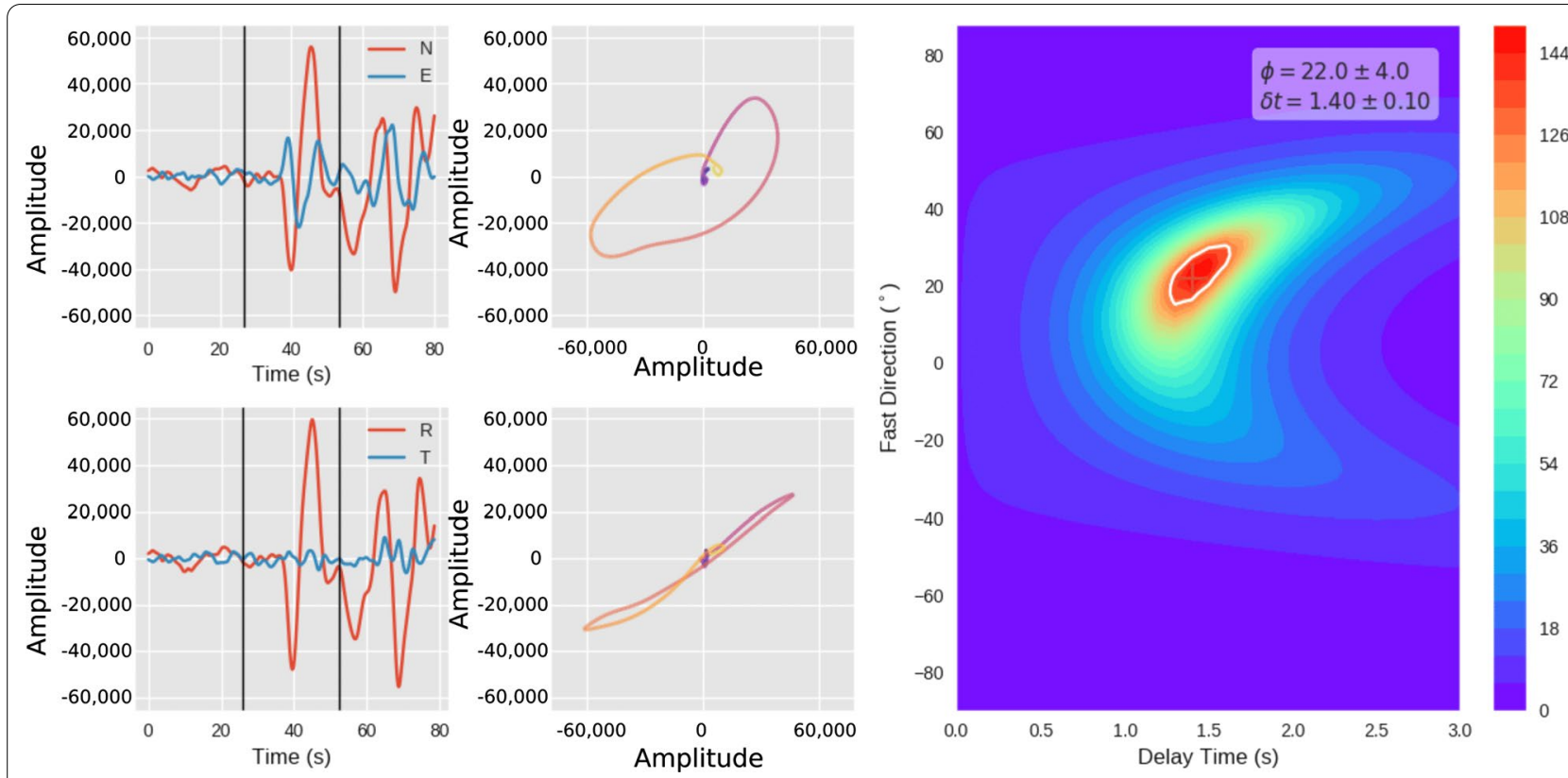

Fig. 9 (Top left) North and East components of the seismogram (same traces as in Figs. 7 and 8), with corresponding particle motion (center).

(Bottom left) Radial and transverse components of the seismogram, with corresponding particle motion (center). (Right) Grid search results used to find the best-fitting parameters for the phase and delay time

the delay time $(\delta t)$ are quite conservative and ensure that the final measurements do not include too many uncertainties.

This grid search (Fig. 9) yielded the fast shear phase $(\phi)$ and a delay time $(\delta t)$. The procedure was repeated at each station and for all respective events. In the end, the average of all the measurements was computed at each station.

\section{Results}

We obtained successful measurements of $H$ and $\kappa$ for a total of 34 stations. Figures 10 and 11 display the receiver function inversions for $H$ and $\kappa$, respectively. Our results suggest that regional thick continental crust (with a thickness of up to $38 \mathrm{~km}$ ) exists beneath the African and Arabian plates, which agrees with previous measurements (Dugda et al. 2005; Dugda and Nyblade 2006; Hammond et al. 2011; Reed et al. 2014; Thompson et al. 2015). In contrast, a very thin crust (with a thickness as low as $21 \mathrm{~km}$ ) is found along the three branches of the continental rifting and beneath the Afar triple junction. This thin crust is consistent with the very thin crustal thickness found beneath the spreading centers and the area of continental break-up (Hammond et al. 2011). Hammond et al. (2011) found that the crustal thickness ranged from $16 \mathrm{~km}$ down the spreading centers in the northern Afar region to
20-25 km near the active rift segments and observed a northward thinning of the crust beneath the Afar triple junction.

$\frac{V_{\mathrm{p}}}{V_{\mathrm{s}}}$ ratio is expected to be in the range 1.7-1.9 in the continental crust (Zandt and Ammon 1995; Musacchio et al. 1997; Kandilarov et al. 2015); most of the measurements in the region (Fig. 11), the value of $\frac{V_{\mathrm{P}}}{V_{\mathrm{s}}}$ is reasonable. However, the measurements observed near the continental rift display relatively high values (greater than 2.0). Note that the receiver function results are not displayed for all stations, as their main primary purpose was to compute $H$ and $\kappa$ using the $H-\kappa$ stacking method (Zhu and Kanamori 2000).

Figure 12 summarizes the shear-wave splitting measurements, and Table 1 lists them in detail. In most of the regions on the Nubian and Somalian plates, the fast direction is oriented NO30E. This fast direction orientation is highly consistent with previous shear-wave splitting measurements (Wüstefeld et al. 2009; IRIS 2012). Along with some additional measurements, we provide detailed information by classifying our results into three categories:

- no data, unreliable measurements (due to insufficient operation time),

- new measurements computed in this study,

- and Null measurements (if number of Null measurements (Wüstefeld and Bokelmann 2007) was 


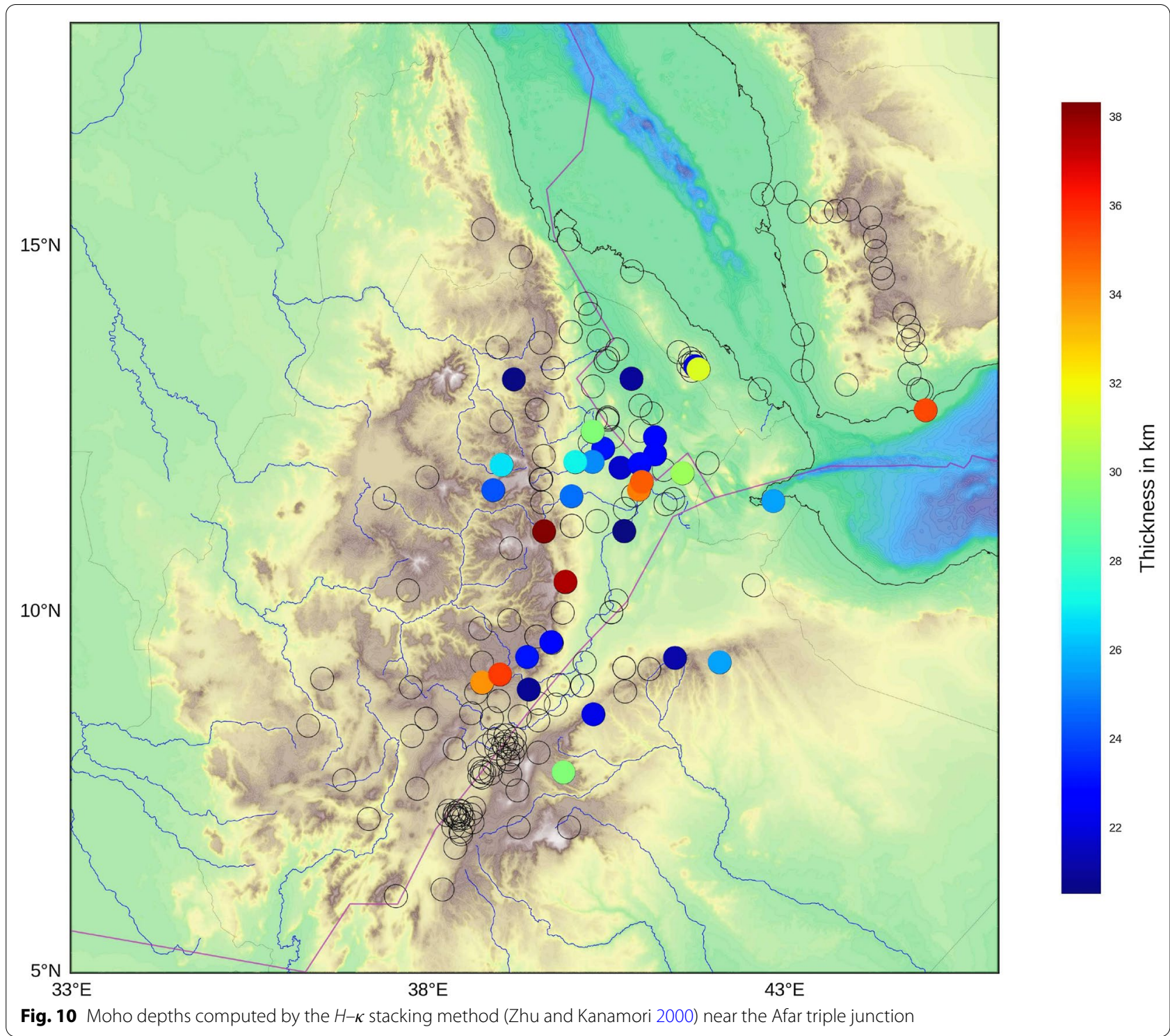

more significant than the number of regular measurements).

Null measurements can occur for several reasons, such as limited data coverage and azimuthal distribution of seismic events. They can also occur if the wave propagates through an isotropic medium, if the wave encounters fluid, if mantle upwelling occurs with a vertical flow of peridotite, or if the initial polarization direction is oriented along either the fast or slow axis. As the incoming shear wave is not split (Savage 1999), it is not possible to determine or accurately. However, in the central part of the rift, there are several stations with fast directions perpendicular to those of the others, at N120E. For several stations, we could only retrieve null measurements or no measurements (e.g., beneath the Arabian Plate), which contrasts with the high scattering present in previous measurements (Wüstefeld et al. 2009; IRIS 2012). In the null measurements, we do not report any direction of $(\phi)$ or $(\delta t)$ in the station summary (Table 1).

\section{Discussion}

\section{Lateral variations of Moho depth}

The results we obtained by inverting the Moho depth receiver functions (Fig. 10) agree well with previous measurements (Dugda et al. 2005; Dugda and Nyblade 2006; Hammond et al. 2011; Reed et al. 2014; Thompson et al. 2015). A thick African crust (40-45 km) is 


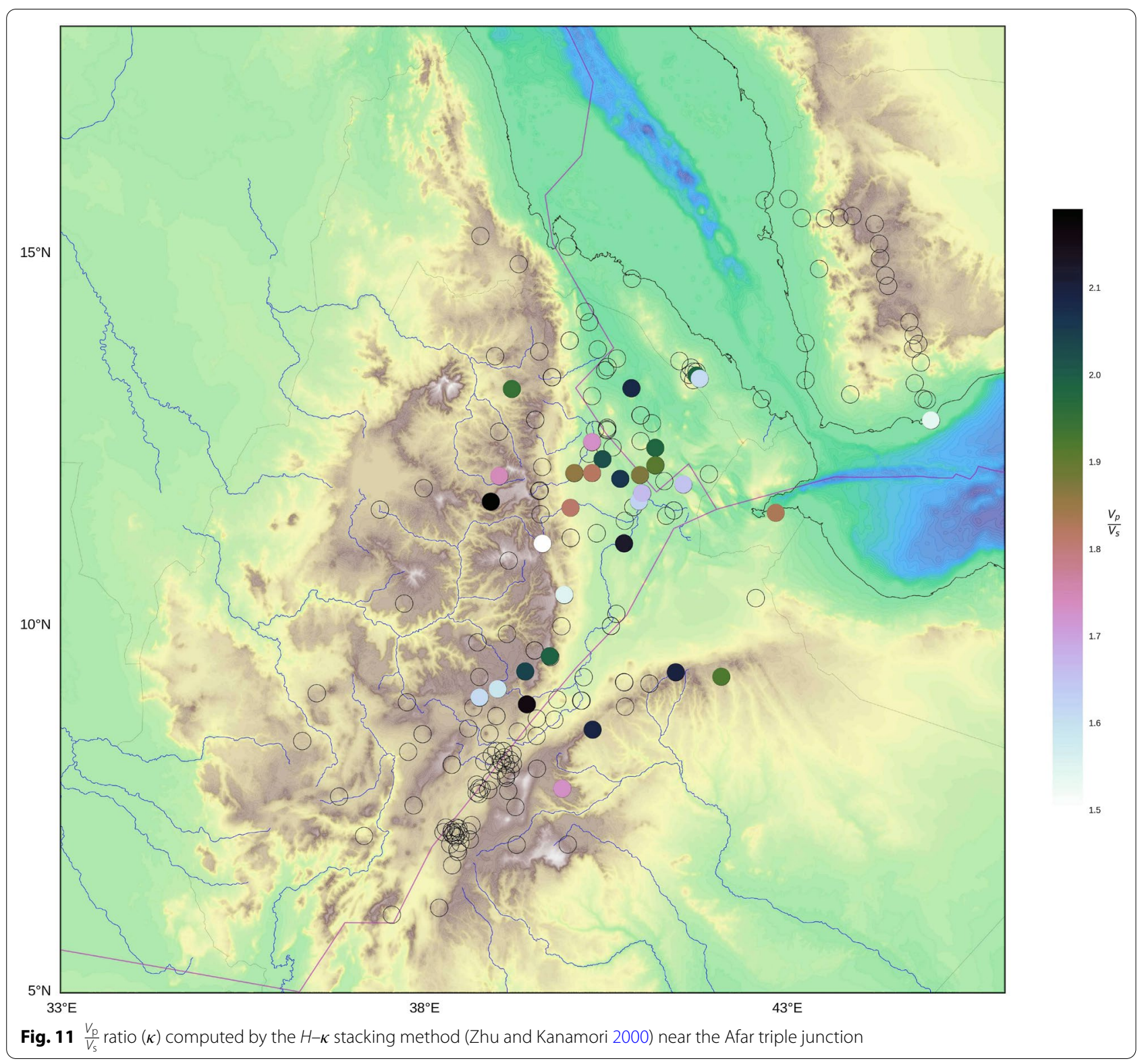

observed near the large igneous volcanic provinces (Wignall 2001; Mège and Korme 2004) beneath the stations located in the continental crust of the Nubian and Somalian plates. These results contrast strongly with the Moho depths we found along the rifts, with a crustal thickness of $21-25 \mathrm{~km}$. This strong dichotomy between the unaltered continental crust and the continental crust thinned by the active continental rifting (Kusky et al. 2010) confirms the theory of the African Plate being split into two tectonic units: the Nubian and Somalian plates (Garfunkel and Beyth 2006).

\section{$\frac{V_{p}}{V_{s}}$ ratio reveals the presence of fluids}

$\frac{V_{\mathrm{p}}}{V_{\mathrm{s}}}$ ratio has been the topic of numerous studies in oceanic (Ćlague and Straley 1977; Hyndman 1979; Bloch et al. 2016), continental (Zandt and Ammon 1995; Musacchio et al. 1997; He et al. 2014), and passive margin domains (Kodaira et al. 1996; Kandilarov et al. 2015). Generally, $\frac{V_{\mathrm{p}}}{V_{\mathrm{s}}}$ has been in the range of 1.7-1.9 for the continental crust.

These values agree well with the results obtained for the stations located far away from the rift system (Fig. 11). 


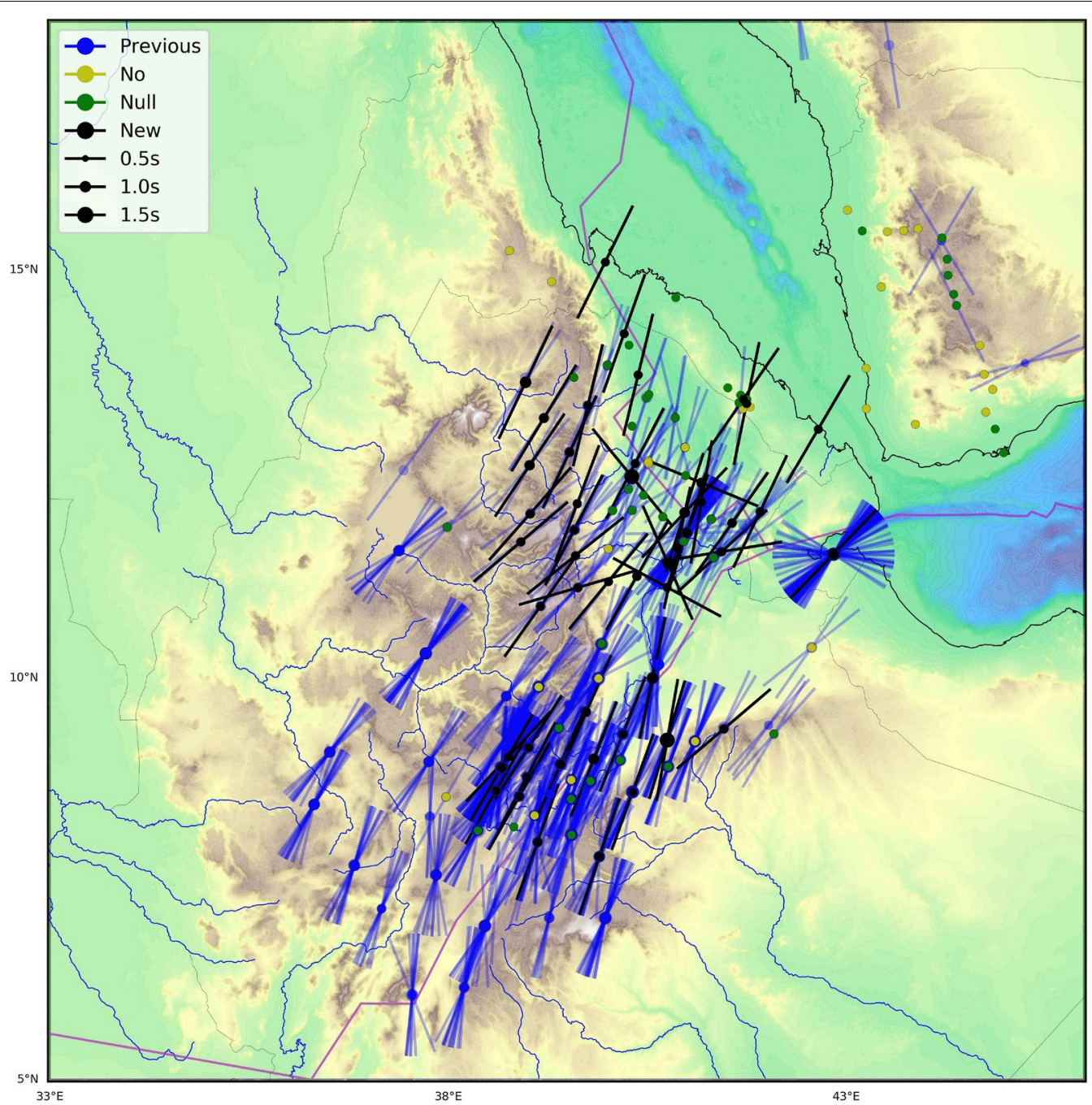

Fig. 12 Shear-wave splitting results for the broadband stations around the Afar triple junction. Blue: previous measurements available from international databases (Wüstefeld et al. 2009; IRIS 2012). Yellow: due to the data quality, no convincing measurements could be obtained. Green: null measurements. Black: each line indicates the mean fast polarization direction given by the median of all observations at one station. The circle size is proportional to the delay time

However, $\frac{V_{\mathrm{p}}}{V_{\mathrm{s}}}$ increases drastically in the regions affected by active rifting (reaching 2.1 , as high as the values found for oceanic domains). This strong contrast of between the unaltered continental crust and thinned crust regions is highly consistent with the mechanical extension of the continental thickness imaged by receiver functions (Fig. 10). The anomalously high $\frac{V_{\mathrm{p}}}{V_{\mathrm{s}}}$, possibly caused by the reduction in shear-velocity $\left(V_{S}\right)$, can be plausible indirect evidence for fluids, melts, or oceanic crust within the rift system branches.

\section{Complex anisotropy beneath the rift system}

Previous shear-wave splitting measurements (Wüstefeld et al. 2009; IRIS 2012) display a constant direction of the fast anisotropy axis throughout the African plate. However, some scattered measurements exist, mainly beneath the Arabian Plate. Our results (Fig. 12) display a similar trend for the stations located on both sides of the rift system beneath the African plates. However, beneath the Arabian Plate, the stations with reliable measurements show null measurements. This null identification suggests that the Arabian block could be isotropic, as it has not experienced substantial deformation since its formation. It is considered a substantially rigid block with limited internal deformation (Alothman et al. 2016; Tesauro et al. 2018) which is consistent with our results. In addition, the high level of inconsistency observed beneath the Arabian plate between the present results and previous 
Table 1 Summary of all shear-wave splitting parameters measured in this study for the Afar triple junction region

\begin{tabular}{|c|c|c|c|c|c|c|c|}
\hline NET & STA & Long. & Lat. & $\phi$ & $\delta t$ & $\mathrm{nb}$ & nb Null \\
\hline $2 \mathrm{H}$ & ABAE & 39.7636 & 13.3535 & 14 & 0 & 1 & 3 \\
\hline $2 \mathrm{H}$ & AFME & 40.8585 & 13.2040 & - & - & 0 & 3 \\
\hline $2 \mathrm{H}$ & AHME & 40.2784 & 14.0889 & - & - & 0 & 3 \\
\hline $2 \mathrm{H}$ & ASYE & 41.4422 & 11.5607 & 48 & 0.7 & 1 & 4 \\
\hline $2 \mathrm{H}$ & BTIE & 40.0218 & 11.1949 & - & - & 0 & 1 \\
\hline $2 \mathrm{H}$ & DALE & 40.2178 & 14.2290 & 20 & 0.1 & 1 & 1 \\
\hline $2 \mathrm{H}$ & DAME & 40.9625 & 11.6868 & - & - & 0 & 1 \\
\hline $2 \mathrm{H}$ & ERTE & 40.4969 & 13.4463 & - & - & 0 & 5 \\
\hline $2 \mathrm{H}$ & GALE & 40.3940 & 13.7251 & 14 & 1.1 & 2 & 3 \\
\hline $2 \mathrm{H}$ & GPSE & 40.5283 & 13.4882 & - & - & 0 & 7 \\
\hline $2 \mathrm{H}$ & GULE & 39.5885 & 13.6945 & - & - & 0 & 2 \\
\hline $2 \mathrm{H}$ & HITE & 40.3169 & 13.1012 & - & - & 0 & 1 \\
\hline $2 \mathrm{H}$ & IGRE & 40.4612 & 12.2526 & - & - & 0 & 1 \\
\hline $2 \mathrm{H}$ & KOZE & 40.9849 & 12.4948 & - & - & 0 & 2 \\
\hline $2 \mathrm{H}$ & LULE & 40.7037 & 11.9892 & - & - & 0 & 2 \\
\hline $2 \mathrm{H}$ & MAYE & 39.5343 & 12.7832 & - & - & 0 & 2 \\
\hline $2 \mathrm{H}$ & SAHE & 40.9770 & 12.0402 & 17.95 & 1.5 & 6 & 2 \\
\hline $2 \mathrm{H}$ & SEME & 41.0043 & 11.7926 & 20.45 & 1.1 & 3 & 4 \\
\hline $2 \mathrm{H}$ & TRUE & 40.3148 & 12.4812 & -40 & 3 & 1 & 3 \\
\hline $4 \mathrm{H}$ & NAB1 & 41.6554 & 13.3873 & - & - & 0 & 2 \\
\hline $4 \mathrm{H}$ & NAB2 & 41.7146 & 13.4285 & 35.39 & 0.5 & 3 & 4 \\
\hline $4 \mathrm{H}$ & NAB3 & 41.7549 & 13.3759 & 12 & 0.3 & 1 & 1 \\
\hline $4 \mathrm{H}$ & NAB4 & 41.6786 & 13.4788 & - & - & 0 & 1 \\
\hline $4 \mathrm{H}$ & NAB7 & 41.7562 & 13.4256 & - & - & 0 & 2 \\
\hline $5 \mathrm{H}$ & ASSE & 42.6545 & 13.0628 & 31 & 1 & 2 & 2 \\
\hline $5 \mathrm{H}$ & DOLE & 39.9806 & 15.0968 & 27 & 0.9 & 2 & 4 \\
\hline $5 \mathrm{H}$ & FAME & 41.5196 & 13.5684 & - & - & 0 & 2 \\
\hline $5 \mathrm{H}$ & TIOE & 40.8666 & 14.6651 & - & - & 0 & 3 \\
\hline $\mathrm{AF}$ & AAUS & 38.7665 & 9.03490 & 43.61 & 0.9 & 5 & 10 \\
\hline $\mathrm{AF}$ & ANKE & 39.7418 & 9.58270 & 24 & 1.2 & 2 & 3 \\
\hline $\mathrm{AF}$ & DESE & 39.6350 & 11.1180 & 74 & 0.6 & 1 & 21 \\
\hline G & ATD & 42.8466 & 11.5307 & 44.73 & 1.5 & 20 & 18 \\
\hline GE & DAMY & 44.3917 & 14.5725 & - & - & 0 & 8 \\
\hline IU & FURI & 38.6798 & 8.89520 & 30.68 & 1.2 & 7 & 31 \\
\hline$X W$ & ADEN & 44.9824 & 12.7759 & - & - & 0 & 3 \\
\hline$X W$ & ANID & 43.2048 & 15.4736 & - & - & 0 & 2 \\
\hline$X W$ & $\mathrm{DABI}$ & 44.2690 & 15.1325 & - & - & 0 & 2 \\
\hline XW & HOTA & 44.8757 & 13.0639 & - & - & 0 & 1 \\
\hline XW & RUSA & 44.3539 & 14.7074 & - & - & 0 & 1 \\
\hline XW & SANA & 44.2068 & 15.3926 & - & - & 0 & 2 \\
\hline XW & YSLE & 44.2816 & 14.9387 & - & - & 0 & 1 \\
\hline YJ & ADEE & 39.9068 & 7.79090 & 19 & 1.1 & 2 & 1 \\
\hline YJ & ADUE & 38.9019 & 8.54040 & 30 & 0.4 & 2 & 1 \\
\hline YJ & ANKE & 39.7339 & 9.59270 & - & - & 0 & 3 \\
\hline YJ & AREE & 39.4188 & 8.93850 & 24 & 1.2 & 3 & 0 \\
\hline YJ & ASEE & 39.1317 & 7.97290 & 20 & 0.9 & 1 & 0 \\
\hline YJ & BEDE & 40.7710 & 8.90860 & - & - & 0 & 1 \\
\hline YJ & BUTE & 38.3824 & 8.11700 & - & - & 0 & 1 \\
\hline YJ & DIKE & 39.5566 & 8.06270 & - & - & 0 & 1 \\
\hline
\end{tabular}


Table 1 (continued)

\begin{tabular}{|c|c|c|c|c|c|c|c|}
\hline NET & STA & Long. & Lat. & $\phi$ & $\delta t$ & $\mathrm{nb}$ & nb Null \\
\hline YJ & DONE & 39.5504 & 8.50900 & - & - & 0 & 1 \\
\hline YJ & DZEE & 38.9959 & 8.78030 & 28 & 0.7 & 1 & 2 \\
\hline YJ & GEWE & 40.5743 & 10.0060 & - & - & 0 & 2 \\
\hline YJ & GTFE & 39.8376 & 9.00340 & 22 & 1.5 & 1 & 0 \\
\hline YJ & KARE & 39.9349 & 10.4224 & - & - & 0 & 1 \\
\hline YJ & KOTE & 39.3961 & 9.38750 & - & - & 0 & 2 \\
\hline YJ & LEME & 38.6095 & 8.61150 & 30 & 0.5 & 1 & 1 \\
\hline YJ & MECE & 40.3241 & 8.59380 & 20 & 0.7 & 1 & 0 \\
\hline YJ & MEKE & 38.8330 & 8.16230 & - & - & 0 & 3 \\
\hline YJ & MELE & 40.2008 & 9.31060 & 22 & 0.2 & 1 & 4 \\
\hline YJ & MIEE & 40.7581 & 9.24160 & 17 & 1.9 & 2 & 0 \\
\hline YJ & NURE & 39.7956 & 8.73120 & - & - & 0 & 1 \\
\hline YJ & SENE & 39.0166 & 9.14660 & 33 & 0.5 & 2 & 2 \\
\hline ZE & AFME & 40.8585 & 13.2040 & - & - & 0 & 7 \\
\hline ZE & AWEE & 40.0719 & 12.0673 & - & - & 0 & 1 \\
\hline ZE & BARE & 40.3556 & 12.6443 & 28 & 0.1 & 1 & 1 \\
\hline ZE & BERE & 41.1886 & 12.1707 & - & - & 0 & 1 \\
\hline ZE & BREE & 41.1883 & 12.1704 & 10 & 0.6 & 1 & 1 \\
\hline ZE & DIGE & 40.2734 & 12.3279 & - & - & 0 & 1 \\
\hline ZE & FINE & 40.3160 & 12.0681 & - & - & 0 & 3 \\
\hline ZE & HARE & 40.8840 & 11.6072 & 12.45 & 0.4 & 3 & 3 \\
\hline ZE & MEGE & 41.3381 & 11.4906 & - & - & 0 & 1 \\
\hline ZE & MILE & 40.7650 & 11.4238 & -24 & 1.6 & 1 & 4 \\
\hline ZE & SEHE & 40.9769 & 12.0401 & 44 & 1.4 & 1 & 2 \\
\hline ZE & SEME & 41.0044 & 11.7926 & 18 & 1.3 & 1 & 3 \\
\hline ZE & SILE & 41.1879 & 12.4070 & 112 & 1.4 & 1 & 3 \\
\hline ZE & TRUE & 40.3161 & 12.4841 & - & - & 0 & 5 \\
\hline ZF & ADTE & 40.7570 & 11.1221 & 118 & 0 & 1 & 4 \\
\hline ZF & ADYE & 38.9811 & 13.6350 & 26 & 1.8 & 3 & 5 \\
\hline ZF & AKEE & 39.1680 & 10.8883 & 36 & 0.4 & 1 & 3 \\
\hline ZF & ASYE & 41.4422 & 11.5607 & 81 & 0.6 & 2 & 2 \\
\hline ZF & AWSE & 40.1700 & 8.98970 & - & - & 0 & 1 \\
\hline ZF & BTIE & 40.0218 & 11.1949 & 40 & 0.9 & 1 & 3 \\
\hline ZF & DERE & 39.6353 & 11.1179 & - & - & 0 & 5 \\
\hline ZF & DICE & 41.5737 & 11.9136 & 36 & 1.2 & 2 & 4 \\
\hline ZF & ELLE & 40.3784 & 11.2579 & 30 & 1.2 & 1 & 7 \\
\hline ZF & ERTE & 40.4969 & 13.4463 & - & - & 0 & 2 \\
\hline ZF & GASE & 38.9211 & 11.6813 & 50.33 & 0.7 & 5 & 0 \\
\hline ZF & GEWE & 40.5739 & 10.0045 & 12 & 1.7 & 1 & 1 \\
\hline ZF & HALE & 40.0077 & 13.8422 & - & - & 0 & 1 \\
\hline ZF & HYNE & 42.0962 & 9.31480 & - & - & 0 & 3 \\
\hline ZF & $\mathrm{KOBE}$ & 39.6298 & 12.1506 & 21 & 1.1 & 2 & 5 \\
\hline ZF & KORE & 39.9344 & 10.4265 & - & - & 0 & 4 \\
\hline ZF & LALE & 39.0375 & 12.0258 & 42 & 0.2 & 2 & 0 \\
\hline ZF & LYDE & 41.9257 & 12.0546 & 26 & 0 & 1 & 3 \\
\hline ZF & MAYE & 39.5343 & 12.7832 & 26 & 1.2 & 6 & 5 \\
\hline ZF & MISE & 40.7591 & 9.23690 & 10 & 3 & 1 & 2 \\
\hline ZF & QATE & 41.4691 & 9.37530 & 50 & 1.1 & 2 & 0 \\
\hline ZF & SEKE & 39.0334 & 12.6217 & 34.67 & 1.4 & 3 & 3 \\
\hline
\end{tabular}


Table 1 (continued)

\begin{tabular}{|c|c|c|c|c|c|c|c|}
\hline NET & STA & Long. & Lat. & $\phi$ & $\delta t$ & $\mathrm{nb}$ & nb Null \\
\hline ZF & SMRE & 39.2111 & 13.1977 & 32 & 1.3 & 1 & 4 \\
\hline ZF & SRDE & 41.3100 & 11.9579 & - & - & 0 & 2 \\
\hline ZF & WLDE & 39.5874 & 11.8243 & 28 & 0.9 & 1 & 1 \\
\hline ZF & WUCE & 39.6064 & 11.5116 & 52 & 0.9 & 1 & 2 \\
\hline ZF & YAYE & 37.9965 & 11.8608 & - & - & 0 & 1 \\
\hline
\end{tabular}

The columns are for the network code, station code, longitude and latitude of the station, phase $(\phi)$, delay time $(\delta t)$, amount of successful measurements and amount of Null measurements. Directions of $(\phi)$ and $\delta t$ are not reported for stations considered to provide mostly null measurements

shear-wave splitting measurements (Wüstefeld et al. 2009; IRIS 2012) displayed in Fig. 12, suggests that the previous measurements in this region were not classified as null, despite the strong angular variations of the fast direction of anisotropy. The highly scattered anisotropy directions measured in previous shear-wave splitting studies strongly suggest the presence of isotropic media beneath the Arabian block.

Close to the triple junction, most of the measurements are oriented NO30E and agree with previous measurements. However, we also found a few measurements perpendicular to the general trend of N120E. The measurements of those outliers are mainly located close to the triple junction. Figure 12 also indicates that the stations located near the rifts tend to display null measurements. Most stations with null measurements are located near the active Holocene volcanoes (Fig. 1). Although null measurements are not present in the global database, the presence of null measurements can be an important indicator of the presence of fluid or melt beneath the rift branches.

\section{Implications for local tectonics}

In this study, 431 new shear-wave splitting measurements were obtained in the investigated region. The average fast direction measured is consistent with the results of Gao et al. (2010). However, the average delay time we found is smaller than that obtained by Gao et al. (2010), which is close to the global average for continents $(1.0 \mathrm{~s}$ calculated from Kennett et al. (1995) and Silver (1996). The fact that the average delay time is slightly smaller than the global average for continental crust can be explained by the presence of thinned continental crust in our target region. The presence of several stations displaying null measurements also agrees with the results of Gao et al. (2010). The relatively homogeneous pattern of the splitting observed in the region suggests that the main contributor to the anisotropy has a deep origin, with local variations associated with crustal heterogeneities. The relatively homogeneous pattern of the splitting is also consistent with the model proposed by Barruol and Ismail (2001), involving a NE flow in the asthenosphere.
In addition to the lateral flow of the asthenosphere, mantle upwelling is also responsible for the presence of fluids and melt, which is in agreement with the high amount of null measurements, as well as the very high values observed around the branches of the Afar rift system. Those observations are consistent with those of body wave (Benoit et al. 2006; Koulakov 2007) and surface wave (Sebai et al. 2006; Guidarelli et al. 2011; Legendre 2013) tomographic models. The presence of very slow velocities beneath the Afar region (for the global and regional models) and beneath the three branches of the rift system at all depths suggests the presence of fluids and melt, linked with potential mantle upwelling. Previous tomographic studies focusing on anisotropy on a large scale (Sebai et al. 2006) or local scale (Korostelev et al. 2015; Sicilia et al. 2008) have revealed large regions with surface wave slow anomalies that are associated with magmatism. Along the rift system, very slow velocities anomalies have been found, suggesting the presence of either partial melt or fluids released by cooling magmatic systems. The local seismicity (Abdallah et al. 1979; Illsley-Kemp et al. 2018) is also very shallow, suggesting the presence of shallow reservoirs in the crust along the rift system. In those regions, our results indicate both thinner crust, higher values of $\frac{V_{\mathrm{p}}}{V_{\mathrm{s}}}$, and the presence of null measurements.

\section{Conclusion}

In this study, we obtained receiver function and shearwave splitting measurements for all 227 available broadband seismic stations deployed in the Afar region. The receiver function results provide additional constraints on the crustal thickness and $\frac{V_{\mathrm{p}}}{V_{\mathrm{s}}}$ ratio. The shear-wave splitting measurements provide some constraints on the average anisotropy over a column encompassing the crust and upper mantle beneath the seismic stations. Here, we found that the thick African crust (with a thickness of $40 \mathrm{~km}$ ) has been strongly elongated and thinned (down to a thickness of $20 \mathrm{~km}$ ) across the rift system. In addition, the exceptionally high $\frac{V_{\mathrm{p}}}{V_{\mathrm{s}}}$ value within the crust along the rifts and numerous null measurements of shearwave splitting for stations located near the rifts suggests 
the presence of melt and the early stage of oceanization. The results of this study provide essential constraints on the structure of the crust and average anisotropy in the Afar region. However, those measurements are limited by the availability of the seismic station deployed in the region. Besides, those measurements provide a 1D snapshot beneath each seismic station, and further modeling such as tomographic inversion could provide a $2 \mathrm{D}$ or $3 \mathrm{D}$ view of the region. The strong lateral variations of crustal thickness, $\frac{V_{\mathrm{p}}}{V_{\mathrm{s}}}$ and seismic anisotropy suggest a more complex pattern with vertical variations that are not visible from our results. However, this study provides accurate measurements of several geophysical parameters that are directly interpreted in terms of the structure and dynamics of the region.

\section{Acknowledgements}

Source code, installation instructions and test input files for STADIUM-Py are freely available for download (Kumar and Legendre 2021).

\section{Authors' contributions}

UK, $\mathrm{CL}$ and BSH contributed to the design and implementation of the research, to the analysis of the results and to the writing of the manuscript. All authors read and approved the final manuscript.

\section{Funding}

This work is funded by the Ministry of Science and Technology under Grants MOST 107-2119-M-001-048; MOST 109-2811-M-001 -608- and MOST 1092116-M-001-021-MY3.

\section{Availability of data and materials}

All data used in this paper came from published sources listed in the references.

\section{Declarations}

\section{Competing interests}

The authors declare no competing interests.

\section{Author details}

${ }^{1}$ Institute of Earth Sciences, Academia Sinica, Taipei, Taiwan. ${ }^{2}$ Institute of Geophysics, Czech Academy of Science, Prague, Czech Republic.

Received: 17 May 2021 Accepted: 11 August 2021

Published online: 25 August 2021

\section{References}

Abdallah A, Courtillot V, Kasser M, Le Dain AY, Lépine JC, Robineau B, Ruegg JC, Tapponnier P, Tarantola A (1979) Relevance of Afar seismicity and volcanism to the mechanics of accreting Plate boundaries. Nature 282(5734):17-23

Alothman A, Fernandes R, Bos M, Schillak S, Elsaka B (2016) Angular velocity of Arabian Plate from multi-year analysis of GNSS data. Arab J Geosci 9(8):529

Ammon CJ, Randall GE, Zandt G (1990) On the nonuniqueness of Receiver Function inversions. J Geophys Res Solid Earth 95(B10):15,303-15,318

Ando M, Ishikawa Y, Yamazaki F (1983) Shear wave polarization anisotropy in the upper mantle beneath Honshu, Japan. J Geophys Res Solid Earth 88(B7):5850-5864

Barruol G, Ismail WB (2001) Upper mantle anisotropy beneath the African iris and geoscope stations. Geophys J Int 146(2):549-561
Benoit MH, Nyblade AA, VanDecar JC (2006) Upper mantle P-wave speed variations beneath Ethiopia and the origin of the Afar hotspot. Geology 34(5):329-332

Bird P (2003) An updated digital model of plate boundaries. Geochem Geophys Geosyst 4(3):1027

Bloch W, John T, Kummerow J, Wigger P, Salazar P, Shapiro S (2016) Watching dehydration: transient vein-shaped porosity in the oceanic mantle of the subducting Nazca slab. EGUGA, pp EPSC2016-6438

Clague DA, Straley PF (1977) Petrologic nature of the oceanic Moho. Geology 5(3):133-136

Doubre C, Deprez A, Masson F, Socquet A, Lewi E, Grandin R, Nercessian A, Ulrich P, De Chabalier JB, Saad I et al (2017) Current deformation in central Afar and triple junction kinematics deduced from GPS and InSAR measurements. Geophys J Int 208(2):936-953

Dugda MT, Nyblade AA (2006) New constraints on crustal structure in eastern Afar from the analysis of receiver functions and surface wave dispersion in Djibouti. Geol Soc Lond Spec Publ 259(1):239-251

Dugda MT, Nyblade AA, Julia J, Langston CA, Ammon CJ, Simiyu S (2005) Crustal structure in Ethiopia and Kenya from receiver function analysis: implications for rift development in eastern Africa. J Geophys Res Solid Earth 110(B1):B01303

Eulenfeld T (2020) rf: Receiver function calculation in seismology. J Open Sour Softw 5(48):1808

Fan X, Chen QF, Legendre C, Guo Z (2020) Intraplate volcanism and regional geodynamics in NE Asia revealed by anisotropic Rayleigh-wave tomography. Geophys Res Lett 47(1):e2019GL085,623

Fukao Y (1984) Evidence from core-reflected shear waves for anisotropy in the Earth's mantle. Nature 309(5970):695

Gao SS, Liu KH, Abdelsalam MG (2010) Seismic anisotropy beneath the Afar depression and adjacent areas: implications for mantle flow. J Geophys Res Solid Earth 115(B12):B12330

Garfunkel Z, Beyth M (2006) Constraints on the structural development of Afar imposed by the kinematics of the major surrounding plates. Geol Soc Lond Spec Publ 259(1):23-42

Gashawbeza EM, Klemperer SL, Nyblade AA, Walker KT, Keranen KM (2004) Shear-wave splitting in Ethiopia: precambrian Mantle anisotropy locally modified by Neogene rifting. Geophys Res Lett 31(18):L18602

Ghebreab W (1998) Tectonics of the Red Sea region reassessed. Earth-Sci Rev 45(1-2): $1-44$

Guidarelli M, Stuart G, Hammond JO, Kendall J, Ayele A, Belachew M (2011) Surface wave tomography across Afar, Ethiopia: crustal structure at a rift triple-junction zone. Geophys Res Lett 38(24):L24313

Hammond JO, Kendall JM, Stuart G, Keir D, Ebinger C, Ayele A, Belachew M (2011) The nature of the crust beneath the Afar triple junction: evidence from receiver functions. Geochem Geophys Geosyst 12(12):Q12004

He R, Shang X, Yu C, Zhang H, Van der Hilst RD (2014) A unified map of Moho depth and $\mathrm{Vp} / \mathrm{Vs}$ ratio of continental China by receiver function analysis. Geophys J Int 199(3):1910-1918. https://doi.org/10.1093/gji/ggu365

Hofmann C, Courtillot V, Feraud G, Rochette P, Yirgu G, Ketefo E, Pik R (1997) Timing of the Ethiopian flood basalt event and implications for plume birth and global change. Nature 389(6653):838-841

Hyndman R (1979) Poisson's ratio in the oceanic crust-a review. Tectonophysics 59(1-4):321-333

Illsley-Kemp F, Keir D, Bull JM, Gernon TM, Ebinger C, Ayele A, Hammond JO, Kendall JM, Goitom B, Belachew M (2018) Seismicity during continental breakup in the Red Sea Rift of northern Afar. J Geophys Res Solid Earth 123(3):2345-2362

IRIS D (2012) Data services products: SWS-DBS shear-wave splitting databases

Joffe S, Garfunkel Z (1987) Plate kinematics of the circum Red Sea-a reevaluation. Tectonophysics 141(1-3):5-22

Kandilarov A, Mjelde R, Flueh E, Pedersen RB (2015) Vp/Vs-ratios and anisotropy on the northern Jan Mayen ridge, north Atlantic, determined from Ocean Bottom Seismic data. Polar Sci 9(3):293-310

Keir D, Belachew M, Ebinger C, Kendall JM, Hammond JO, Stuart G, Ayele A Rowland J (2011) Mapping the evolving strain field during continental breakup from crustal anisotropy in the Afar depression. Nat Commun 2(1):1-7

Kennett BL, Engdahl E, Buland R (1995) Constraints on seismic velocities in the Earth from traveltimes. Geophys J Int 122(1):108-124 
Kind R, Yuan X, Mechie J, Sodoudi F (2015) Structure of the upper mantle in the north-western and central united states from us arrays-receiver functions. Solid Earth 6(3):957-970. https://doi.org/10.5194/se-6-957-2015

Kodaira S, Bellenberg M, Iwasaki T, Kanazawa T, Hirschleber HB, Shimamura H (1996) Vp/ Vs ratio structure of the Lofoten continental margin, northern Norway, and its geological implications. Geophys J Int 124(3):724-740. https://doi.org/10.1111/j.1365-246X.1996.tb05634.x

Koptev A, Gerya T, Calais E, Leroy S, Burov E (2018) Afar triple junction triggered by plume-assisted bi-directional continental break-up. Sci Rep 8(1):1-7

Korostelev F, Weemstra C, Leroy S, Boschi L, Keir D, Ren Y, Molinari I, Ahmed A, Stuart GW, Rolandone F et al (2015) Magmatism on rift flanks: insights from ambient noise phase velocity in Afar region. Geophys Res Lett 42(7):2179-2188

Koulakov IY (2007) Structure of the Afar and Tanzania plumes based on the regional tomography using ISC data. In: Doklady earth sciences, Citeseer, vol 417, p 1287

Kumar U, Legendre CP (2021) STADIUM-Py: Python command-line interface for automated receiver functions and shear-wave splitting measurements. Zenodo. https://doi.org/10.5281/zenodo.4686103

Kusky TM, Toraman E, Raharimahefa T, Rasoazanamparany C (2010) Active tectonics of the Alaotra-Ankay graben system, Madagascar: possible extension of Somalian-African diffusive plate boundary? Gondwana Res 18(2-3):274-294

Langston CA (1979) Structure under Mount Rainier, Washington, inferred from teleseismic body waves. J Geophys Res Solid Earth 84(B9):4749-4762

Legendre C (2013) Shear wave velocity model of the upper mantle beneath Europe and surroundings. Doctoral Thesis, Ruhr-Universität Bochum, Universitätsbibliothek

Legendre C, Zhao L, Deschamps F, Chen QF (2016) Layered anisotropy within the crust and lithospheric mantle beneath the Sea of Japan. J Asian Earth Sci 128:181-195

Legendre C, Tseng T, Zhao L (2020) Surface-wave phase-velocity maps of the Anatolia region (Turkey) from ambient noise tomography. J Asian Earth Sci 193:104322

Legendre CP, Tseng TL, Chen YN, Huang TY, Gung YC, Karakhanyan A, Huang BS (2017) Complex deformation in the Caucasus region revealed by ambient noise seismic tomography. Tectonophysics 712:208-220

Maguire R, Ritsema J, Goes S (2018) Evidence of subduction-related thermal and compositional heterogeneity below the United States from transition zone receiver functions. Geophys Res Lett 45(17):8913-8922

McClusky S, Reilinger R, Ogubazghi G, Amleson A, Healeb B, Vernant P, Sholan J, Fisseha S, Asfaw L, Bendick R et al (2010) Kinematics of the southern Red Sea-Afar triple junction and implications for Plate dynamics. Geophys Res Lett 37(5):L05301

McQuarrie N, Stock J, Verdel C, Wernicke B (2003) Cenozoic evolution of Neotethys and implications for the causes of plate motions. Geophys Res Lett 30(20):2036

Mège D, Korme T (2004) Dyke swarm emplacement in the Ethiopian Large Igneous Province: not only a matter of stress. J Volcanol Geotherm Res 132(4):283-310

Megies T, Beyreuther M, Barsch R, Krischer L, Wassermann J (2011) Obspy-what can it do for data centers and observatories? Ann Geophys 54(1):47-58

Mohr P (1970) The Afar triple junction and sea-floor spreading. J Geophys Res 75(35):7340-7352

Musacchio G, Mooney WD, Luetgert JH, Christensen NI (1997) Composition of the crust in the Grenville and Appalachian provinces of North America inferred from Vp/Vs ratios. J Geophys Res Solid Earth 102(B7):15225-15241

Ni S, Tan E, Gurnis M, Helmberger D (2002) Sharp sides to the African Superplume. Science 296(5574):1850-1852

Obrebski M, Kiselev S, Vinnik L, Montagner JP (2010) Anisotropic stratification beneath Africa from joint inversion of SKS and $P$ receiver functions. J Geophys Res Solid Earth 115(B9):B09313

Reed CA, Almadani S, Gao SS, Elsheikh AA, Cherie S, Abdelsalam MG, Thurmond AK, Liu KH (2014) Receiver function constraints on crustal seismic velocities and partial melting beneath the Red Sea rift and adjacent regions, Afar depression. J Geophys Res Solid Earth 119(3):2138-2152
Reilinger R, McClusky S (2011) Nubia-Arabia-Eurasia plate motions and the dynamics of mediterranean and middle east tectonics. Geophys J Int 186(3):971-979

Rychert CA, Hammond JO, Harmon N, Kendall JM, Keir D, Ebinger C, Bastow ID, Ayele A, Belachew M, Stuart G (2012) Volcanism in the Afar rift sustained by decompression melting with minimal plume influence. Nat Geosci 5(6):406-409

Savage MK (1999) Seismic anisotropy and mantle deformation: what have we learned from shear wave splitting? Rev Geophys 37(1):65-106. https:// doi.org/10.1029/98RG02075

Schilling JG, Kingsley RH, Hanan BB, McCully BL (1992) Nd-Sr-Pb isotopic variations along the gulf of aden: Evidence for Afar mantle plume-continental lithosphere interaction. J Geophys Res Solid Earth 97(B7):10,927-10,966

Sebai A, Stutzmann E, Montagner JP, Sicilia D, Beucler E (2006) Anisotropic structure of the African upper mantle from Rayleigh and love wave tomography. Phys Earth Planet Inter 155(1-2):48-62

Sicilia D, Montagner JP, Cara M, Stutzmann E, Debayle E, Lépine JC, Lévêque JJ, Beucler E, Sebai A, Roult G et al (2008) Upper mantle structure of shear-waves velocities and stratification of anisotropy in the Afar hotspot region. Tectonophysics 462(1-4):164-177

Silver PG (1996) Seismic anisotropy beneath the continents: probing the depths of geology. Annu Rev Earth Planet Sci 24(1):385-432

Simmons NA, Forte AM, Grand SP (2007) Thermochemical structure and dynamics of the African Superplume. Geophys Res Lett 34(2):L02301

Tesauro M, Kaban MK, Petrunin AG, El Khrepy S, Al-Arifi N (2018) Strength and elastic thickness variations in the Arabian plate: a combination of temperature, composition and strain rates of the lithosphere. Tectonophysics 746:398-411

Tesfaye S, Harding DJ, Kusky TM (2003) Early continental breakup boundary and migration of the Afar triple junction, Ethiopia. GSA Bull 115(9):1053-1067

Thompson D, Hammond JO, Kendall JM, Stuart G, Helffrich G, Keir D, Ayele A, Goitom B (2015) Hydrous upwelling across the Mantle Transition Zone beneath the Afar triple junction. Geochem Geophys Geosyst 16(3):834-846

Trabant C, Hutko AR, Bahavar M, Karstens R, Ahern T, Aster R (2012) Data products at the IRIS DMC: stepping stones for research and other applications. Seismol Res Lett 83(5):846-854

Venzke E (2013) Global volcanism program, 2013. Volcanoes of the world, v 4.5. 2

Walker KT, Bokelmann GH, Klemperer SL, Nyblade A, Walker K, Bokelmann G, Klemperer S, Nyblade A (2005) Shear wave splitting around hotspots: evidence for upwelling-related mantle flow? Spec Pap Geol Soc Am 388:171

Walpersdorf A, Vigny C, Ruegg JC, Huchon P, Asfaw LM, Kirbash SA (1999) 5 years of GPS observations of the Afar triple junction area. J Geodyn 28(2):225-236

Walpole J, Wookey J, Masters G, Kendall J (2014) A uniformly processed data set of SKS shear wave splitting measurements: a global investigation of upper mantle anisotropy beneath seismic stations. Geochem Geophys Geosyst 15(5):1991-2010

Wignall PB (2001) Large igneous provinces and mass extinctions. Earth-Sci Rev 53(1-2):1-33

Wüstefeld A, Bokelmann G (2007) Null detection in shear-wave splitting measurements. Bull Seismol Soc Am 97(4):1204-1211

Wüstefeld A, Bokelmann G, Barruol G, Montagner JP (2009) Identifying global seismic anisotropy patterns by correlating shear-wave splitting and surface-wave data. Phys Earth Planet Inter 176(3-4):198-212

Zandt G, Ammon CJ (1995) Continental crust composition constrained by measurements of crustal Poisson's ratio. Nature 374(6518):152-154

Zhu L, Kanamori H (2000) Moho depth variation in southern California from teleseismic receiver functions. J Geophys Res Solid Earth 105(B2):2969-2980

\section{Publisher's Note}

Springer Nature remains neutral with regard to jurisdictional claims in published maps and institutional affiliations. 